\title{
The retreat of Jones Ice Shelf, Antarctic Peninsula
}

\author{
Adrian J. FOX, David G. VAUGHAN \\ British Antarctic Survey, Natural Environment Research Council, Madingley Road, Cambridge CB3 OET, UK \\ E-mail: a.fox@bas.ac.uk
}

\begin{abstract}
In recent decades, several ice shelves along the Antarctic Peninsula have diminished in size as a result of climate warming. Using aerial photographic, satellite and survey data we document a similar retreat of Jones Ice Shelf, which was another small ice shelf on the west coast of the Antarctic Peninsula. This ice shelf was roughly stable between 1947 and 1969, but in the early 1970s it began to retreat and had completely disappeared by early 2003. Jones Ice Shelf has two ice fronts only a few kilometres apart and its retreat provides a unique opportunity to examine how different ice fronts retreat when subjected to similar climate forcing. We mapped the retreat of both the east and west ice fronts of Jones Ice Shelf and found that, although individual episodes of retreat may be related to particularly warm summers, the overall progress of retreat of the two ice fronts has been rather different. This suggests that in this case the course of retreat is controlled by the geometry of the embayment and location of pinning points as well as climatic events.
\end{abstract}

\section{INTRODUCTION}

The absence of ice shelves along the northwest coast of the Antarctic Peninsula prompted Mercer (1978) to propose the existence of a climatic limit of viability for ice shelves. He went on to predict that atmospheric warming would cause a southerly migration of this limit of viability and a loss of ice shelves. Since Mercer made his predictions, warming has taken place on the Antarctica Peninsula (see Vaughan and others, 2001 for a recent assessment of this warming) and many ice shelves around the Antarctic Peninsula have indeed shown evidence of retreat: Wordie Ice Shelf (Doake and Vaughan, 1991); Prince Gustav Ice Shelf and the ice shelf that formerly occupied Larsen Inlet, Larsen A ice shelf (Vaughan and Doake, 1996); Müller Ice Shelf (Ward, 1995); Wilkins Ice Shelf (Scambos and others, 2000); George VI Ice Shelf (Lucchitta and Rosanova, 1998); and most recently, Larsen B ice shelf (Scambos and others, 2003). The pattern and rate of ice-shelf retreat appears consistent with the key driver being atmospheric warming (Vaughan and Doake, 1996), and various mechanisms have been implicated in driving retreat (Scambos and others, 2003) and final-stage collapse (Doake and others, 1998; MacAyeal and others, 2003). A similar pattern of retreat, that also appears to be linked to climate change, has been noted in marine and tidewater glaciers along the west coast of the Antarctic Peninsula (Cook and others, 2005).

Jones Ice Shelf is the only ice shelf of significant size on the west coast of the Antarctic Peninsula whose history remains to be described, but given its location, $25 \mathrm{~km}$ south of Müller Ice Shelf and $200 \mathrm{~km}$ north of Wordie Ice Shelf, its retreat is required to complete the pattern of retreat and confirm that it conforms with the progression of the limit of viability (Morris and Vaughan, 2003). Here, we present a history for Jones Ice Shelf, and discuss its implications for our understanding of ice-shelf retreat.

Jones Ice Shelf was located among islands on the west

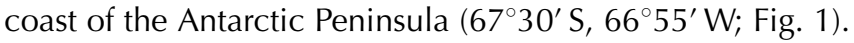
It was first traversed and surveyed in 1949 by members of the Falkland Islands Dependencies Survey (HattersleySmith, 1991, p.316). At that time it was about $9.5 \mathrm{~km}$ long, a little less than $25 \mathrm{~km}^{2}$ in area and it blocked Jones Channel between Bigourdan Fjord and Bourgeois Fjord
(Fig. 2). Jones Ice Shelf was unusual in having two separate ice fronts, one calving into Bigourdan Fjord, the other into Bourgeois Fjord. Glacier flowlines and the sparse radioecho sounding data available (BEDMAP, www.antarctica. ac.uk.bedmap) indicate that the shelf ice was non-porous and therefore glacier-derived, mainly from the $10 \mathrm{~km}$ long Heim Glacier, which flows south from a $150 \mathrm{~km}^{2}$ catchment, part of a large ice field on the Antarctic Peninsula. This ice field also feeds the $50 \mathrm{~km}^{2}$ Müller Ice Shelf to the north. Photogrammetric measurements of the ice-shelf surface altitude (Fig. 3) suggest a maximum draft in 1989 of about 180-200 m, thinning to about $50 \mathrm{~m}$ near the ice fronts. Jones Ice Shelf has never been the subject of a systematic study, so few other data exist for it: the bathymetry of the Jones Channel is unknown, and we are not aware of any field measurements of ice velocity, strain

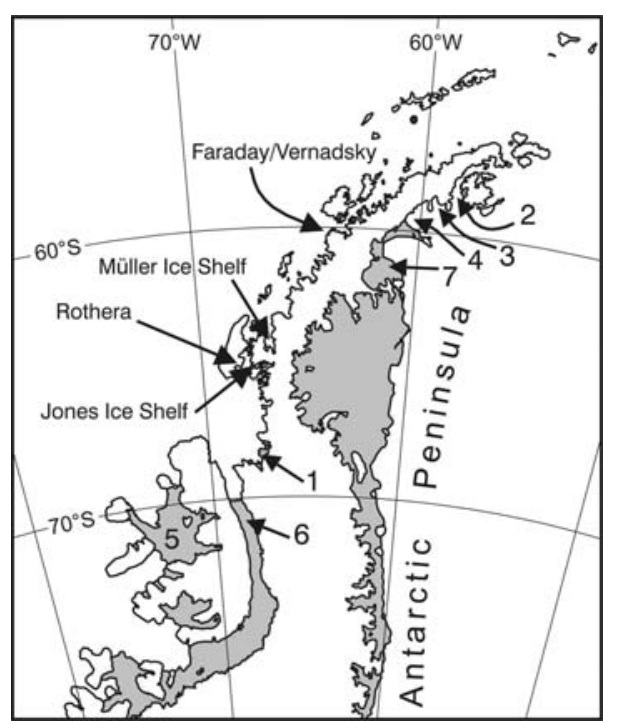

Fig. 1. Location map for the Antarctic Peninsula. The ice shelves mentioned in the text are numbered. 1: Wordie Ice Shelf, 2: Prince Gustav Ice Shelf, 3: the ice shelf that formerly occupied Larsen Inlet, 4: Larsen A ice shelf, 5: Wilkins Ice Shelf, 6: George VI Ice Shelf, 7: Larsen B ice shelf. 


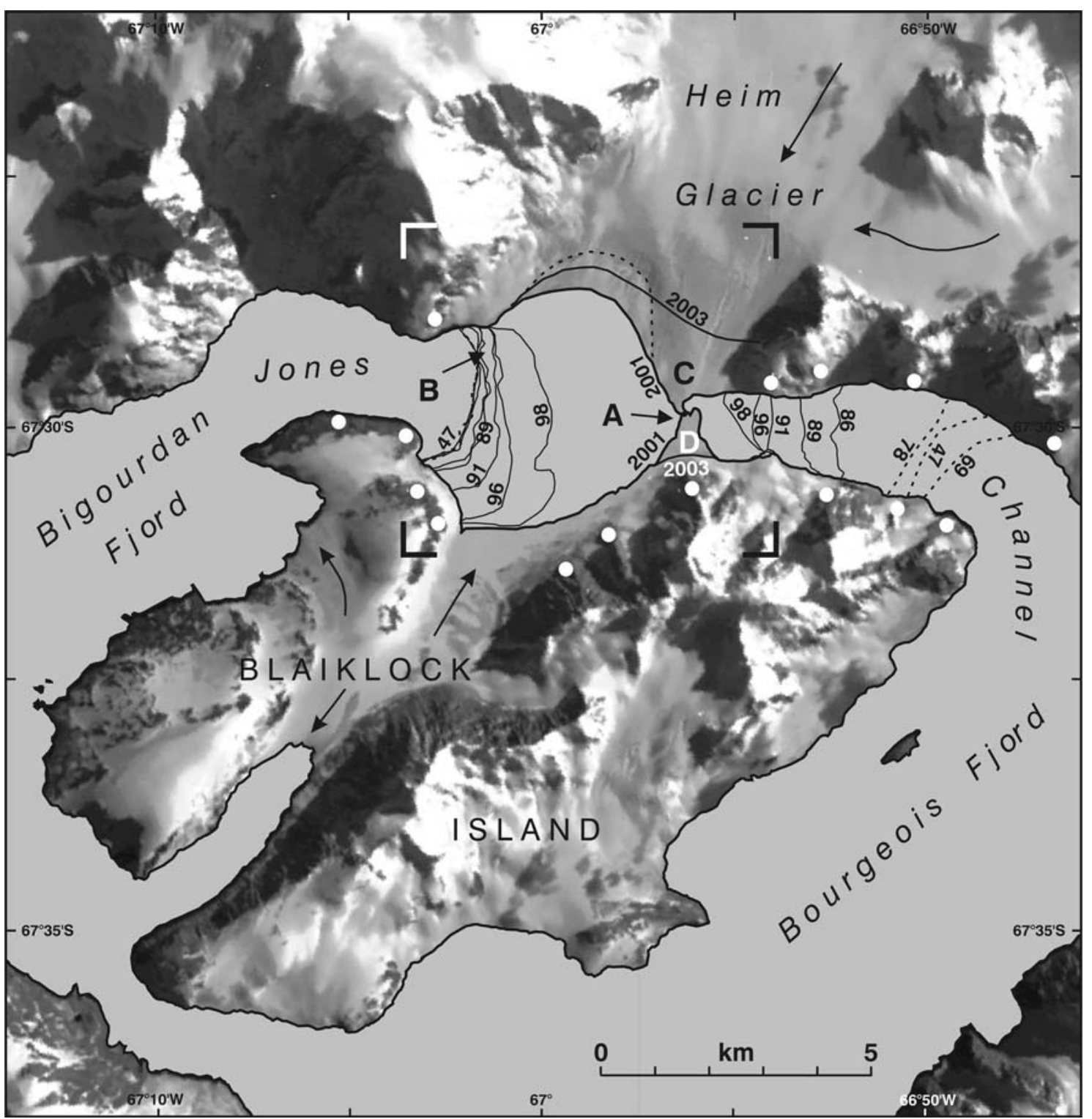

Fig. 2. Positions of the ice front of Jones Ice Shelf derived from the data sources listed in Table 1. Vertical aerial photography and Landsat Thematic Mapper (reliability better than $\pm 90 \mathrm{~m}$ ): 1986, 1989, 1991, 1996, 1998, 2001, 2003. Oblique aerial photography (better than $\pm 300 \mathrm{~m}$ ): 1947, 1969. Landsat multispectral scanner (mixed reliability): 1978. The boundary between the west and east ice shelves is a line between $\mathrm{C}$ and $\mathrm{D}$. Arrows indicate glacier flow direction. White discs denote rock outcrops used in the geo-referencing process. The corner ticks define the area covered in Figure $5 b$.

rate, accumulation or the basal melting rate. Since it is no longer possible to make such measurements, we have restricted this study to a presentation of evidence from archival aerial photography and satellite imagery, and a discussion of whether the retreat of Jones Ice Shelf conforms to two of the most important theories concerning iceshelf retreat.

\section{METHODS}

We used a section of a Landsat Thematic Mapper image from February 1986 as a base image to which further images and aerial photographs from various dates were georeferenced (Table 1 ). The base image (pixel size $30 \mathrm{~m}$ ) was fixed to the British Antarctic Survey (BAS) triangulationtrilateration geodetic survey network by the Bundesamt für Kartographie und Geodäsie (formerly Institut für Angewandte Geodäsie (IfAG)), Germany, as part of a wider collaboration for topographic mapping. The method was described by Sievers and others (1989). Ice fronts from vertical aerial photographs were fixed to the base image with an accuracy of better than \pm 3 pixels $(90 \mathrm{~m})$, but those from oblique aerial photographs and a low-resolution Landsat multispectral scanner (MSS) image were positioned to better than \pm 10 pixels $(300 \mathrm{~m}$ ). The method of acquisition is used to categorize the reliability of the geo-referencing of the data sources. Ice-shelf front positions for the various years were then digitized on screen into a Geographicel Information System (Arc/Info).

\section{Vertical aerial photography}

Ice front positions for 1957, 1991, 1996, 1998, 2001 and 2003 were interpreted from vertical aerial photography at scales ranging from $1: 20000$ to $1: 30000$, and overlaid onto the base image using rock outcrops visible on both photography and imagery as a guide (Fig. 2). 
The geodetic survey network in this sparsely surveyed area was insufficient for photogrammetric mapping of the ice front positions from these photographs, but the larger ground coverage of the 1:70000 scale IfAG photographs (1989) did include enough ground control for photogrammetry. Comparison between the photogrammetric ice fronts and those compiled by manual plotting from the photography onto the satellite image base map showed that the latter method could be carried out with an accuracy of better than $\pm 90 \mathrm{~m}$ for vertical aerial photography.

\section{Oblique aerial photography}

The ice front positions for 1947 and 1969 were plotted from oblique aerial photography only. These positions have greater uncertainty and were given a lower reliability. Image quality and position in the depth of field of the photography are the key determinants of registration accuracy. The photo quality for the 1947 and 1969 data is acceptable and the ice fronts are well positioned in the photographs and in the narrower parts of Jones Channel, close to conspicuous rock outcrops, allowing their positions to be determined with an accuracy of better than $300 \mathrm{~m}$.

\section{Satellite imagery}

The ice front position for 1986 was digitized directly from the base image and so is accurate to the $30 \mathrm{~m}$ resolution of the image. The ice front positions for 1978 are derived from $90 \mathrm{~m}$ resolution Landsat MSS imagery. The western ice front can be clearly seen on the image and was plotted accurate to the resolution of the imagery. Differentiating between the ice shelf and sea ice is difficult for the eastern ice front and this position is more approximate.

\section{DISCUSSION}

The positions of the ice fronts of Jones Ice Shelf shown in Figure 2 allowed us to calculate the areal changes for the east and west portions and for the complete ice shelf (Fig. 4a). There has been a clear retreat of Jones Ice Shelf since 1947, culminating in disconnection of the ice shelf from Blaiklock

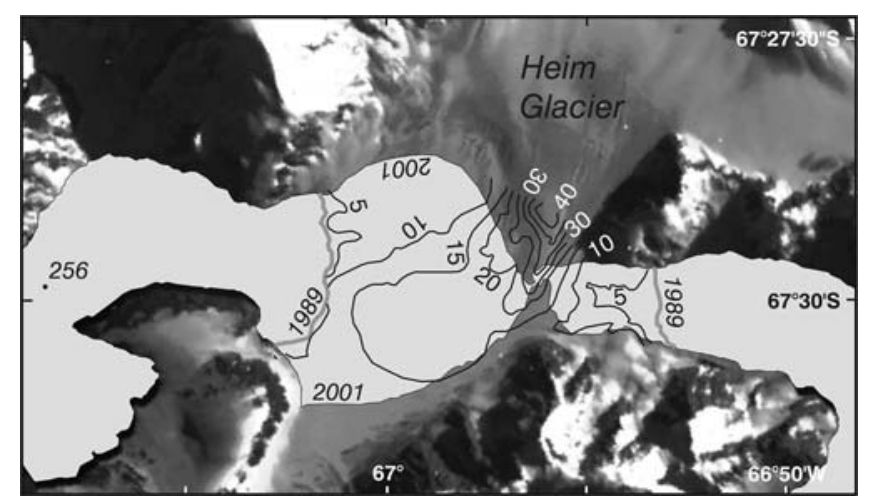

Fig. 3. Photogrammetric measurement of the surface elevation of Jones Ice Shelf from IfAG aerial photography (1989). Contour values are in metres. The $25 \mathrm{~m}$ contour corresponds closely with the fragment of ice remaining in 2001.

Island at 'A' (Fig. 2) sometime between December 1998 and January 2001, and complete disappearance by January 2003. These changes are sufficient to confirm that Jones Ice Shelf retreated during the latter half of the 20th century, which is entirely in line with the earlier predictions (Mercer 1978; Vaughan and Doake 1996) and thus provides confirmation that all the ice shelves close to the limit of viability have retreated over this period (Morris and Vaughan, 2003).

The retreat histories of neighbouring ice shelves - Wordie Ice Shelf, $200 \mathrm{~km}$ to the south and Müller Ice Shelf, $25 \mathrm{~km}$ to the north - have already been described. Wordie Ice Shelf advanced slightly between 1937 and 1966, but began a rapid retreat between 1966 and 1974 (Vaughan and Doake, 1996). Müller Ice Shelf, however, showed a substantial advance between 1947 and 1956, followed by an intermittent retreat to the present (Ward, 1995). Although the observations available for the Jones, Müller and Wordie ice shelves are not always simultaneous, the following comparisons can be drawn. The retreat history of the eastern portion of Jones Ice Shelf is very similar to that of Wordie Ice Shelf (see fig. 2 of Vaughan and Doake, 1996), with a minor

Table 1. Summary of data sources used. No image scale is given for satellite imagery or oblique aerial photography

\begin{tabular}{|c|c|c|c|c|}
\hline Image source & Date & Type & $\begin{array}{l}\text { Height }(\mathrm{ft} / \mathrm{m}) \\
\text { Image-scale }\end{array}$ & Reliability \\
\hline Falkland Islands Dependencies Aerial Survey Expedition (FIDASE) & Jan 1957 & Vertical & $\begin{array}{l}13500 / 4100 \\
1: 27000\end{array}$ & better than $\pm 90 \mathrm{~m}$ \\
\hline US Navy Trimetrogon aerial photography (TMA) & Jan 1969 & Oblique & $19000 / 5800$ & better than $\pm 300 \mathrm{~m}$ \\
\hline Landsat multispectral scanner (MSS) & Dec 1978 & Satellite & & better than $\pm 300 \mathrm{~m}$ \\
\hline Landsat Thematic Mapper (TM) & Feb 1986 & Satellite & & $\pm 30 \mathrm{~m}$ \\
\hline Institut für Angewandte Geodäsie (IfAG) & Feb 1989 & Vertical & $\begin{array}{l}19000 / 5800 \\
1: 70000\end{array}$ & better than $\pm 90 \mathrm{~m}$ \\
\hline British Antarctic Survey & Jan 1991 & Vertical & $\begin{array}{l}10000 / 3000 \\
1: 20000\end{array}$ & better than $\pm 90 \mathrm{~m}$ \\
\hline British Antarctic Survey & Dec 1996 & Vertical & $\begin{array}{l}12500 / 3800 \\
1: 25000\end{array}$ & better than $\pm 90 m$ \\
\hline British Antarctic Survey & Dec 1998 & Vertical & $\begin{array}{l}12500 / 3800 \\
1: 25000\end{array}$ & better than $\pm 90 \mathrm{~m}$ \\
\hline British Antarctic Survey & Jan 2001 & Vertical & $\begin{array}{l}15000 / 4600 \\
1: 30000\end{array}$ & better than $\pm 90 \mathrm{~m}$ \\
\hline British Antarctic Survey & Jan 2003 & Vertical & $\begin{array}{l}15000 / 4600 \\
1: 30000\end{array}$ & better than $\pm 90 \mathrm{~m}$ \\
\hline
\end{tabular}



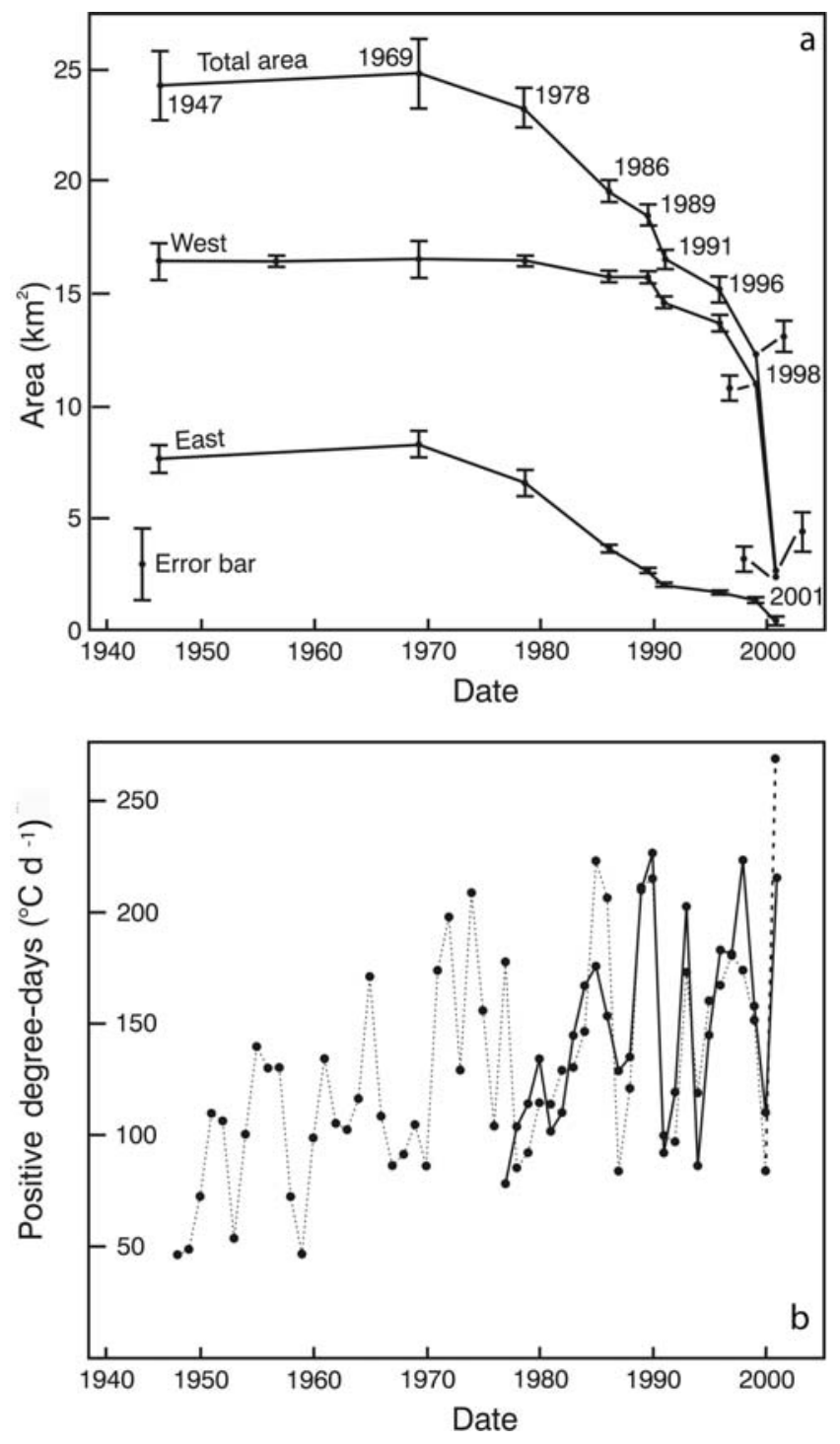

Fig. 4. (a) Area of ice shelf calculated from ice fronts shown in Figure 2. (b) The total positive degree-days for each austral summer calculated from 3 and 1 hourly temperature observations at Faraday/ Vernadsky Station (dashed line) and Rothera Station (full line).

advance from 1947 to 1969, followed by a generally progressive retreat. The retreat history for the western portion of Jones Ice Shelf was different, with no strong evidence for retreat before 1991, and thereafter accelerating retreat and eventually a relatively sudden and almost complete collapse by 2001. This is more comparable to ice shelves on the eastern coast of the Antarctic Peninsula (e.g. Prince Gustav Ice Shelf; see fig. 2 of Vaughan and Doake, 1996).

The differences between the progress of retreat on the eastern and western ice fronts are significant: Since the two ice fronts are only about $10 \mathrm{~km}$ apart and they are similarly sheltered from ocean swells by the topography, remnant sea ice and floating ice in the Jones Channel, we assume that they experienced similar climatic driving and hence provide a unique opportunity for comparison (Fig. 2). In one aspect, however, they were clearly different: the embayment that contained the eastern, Bourgeois Fjord side, portion of Jones Ice Shelf widens from $1 \mathrm{~km}$ wide at the 1996 ice front position, to $2.6 \mathrm{~km}$ at the position of the 1947 ice front. Ice flow in this portion of the ice shelf was thus generally divergent. In contrast, ice flow in the western, Bigourdan Fjord portion of Jones Channel was convergent, closing from its maximum width of $4.6 \mathrm{~km}$ near the 1998 ice front position, to only $1.75 \mathrm{~km}$ at its narrowest point at the northern tip of Blaiklock Island. The effect of this convergent embayment was reinforced by the presence of a small ice rise at ' $\mathrm{B}$ ' in Figure 2, which acted as a pinning point, further constricting flow.

According to the analysis of the retreat and eventual collapse of Larsen B ice shelf presented by Doake and others (1998), these contrasting, divergent and convergent ice-flow regimes would have created substantially different strainrate regimes, resulting in a different progression of retreat in each part of the ice shelf. Doake and others (1998) described a 'compressive arch', which will occur under convergent ice flow patterns, in which one of the principal strain rates in the ice shelf is compressive. The compressive arch is generated across the ice shelf, curving inland between pinning points at the narrowest point in the embayment, and is analogous to the arch of compressive forces that allows a vertical stone arch to be stable even after erosion of material from its underside. The discussion by Doake and others suggested that the presence of a strong compressive arch would affect the progress of retreat of the ice shelf; while the arch remained intact it would impede further ice front retreat, but, once the arch was breached, rapid retreat and perhaps collapse was likely to occur.

In the case of Jones Ice Shelf, the western arm, with the strongly convergent ice flow required to pass through the narrow ice front and past pinning point ' $\mathrm{B}$ ', would have produced a strong compressive arch, but the eastern portion, having generally divergent ice flow, and hence extensive strain rates in both principal directions, would not. Our observations show that Doake and others' interpretation of the importance of the compressive arch in controlling the progress of retreat appears to be supported on Jones Ice Shelf. In the eastern portion (in the divergent bay and without a strong compressive arch) retreat occurred almost linearly in time, while in the western portion (in the convergent bay and with a strong compressive arch) retreat was much slower for several decades and then collapse proceeded rapidly. This behaviour appears to confirm that while climatic conditions initiate and drive ice-shelf retreat, the pattern of the retreat is strongly affected by the geometry of the embayment. Furthermore, some ice-shelf geometries could slow the progress of ice-shelf retreat but eventually lead to the rapid collapse, while other geometries lead to more progressive change.

Direct measurements of ice thickness on Jones Ice Shelf are sparse. In 1974/75 the western portion was found to be between 170 and $250 \mathrm{~m}$ thick, and in 1994/95 the eastern portion was between 150 and $200 \mathrm{~m}$. However, the surface elevation measured from the 1989 photogrammetry gives some indication of the ice thickness at that time (Fig. 3), showing a thinner portion of ice in the northwest. The subsequent pattern of retreat was not preferentially across this thin area, suggesting that the ice thickness was not a key factor in determining the pattern of retreat. The lack of repeated measurements of ice thickness means it is not possible to determine if a change in the basal melt rate was important, as was suggested by Shepherd and others, for Larsen B (2003).

While the record from Jones Ice Shelf does appear to support the idea of a geometric control on the progress of ice 
a IfAG photography, February 1989

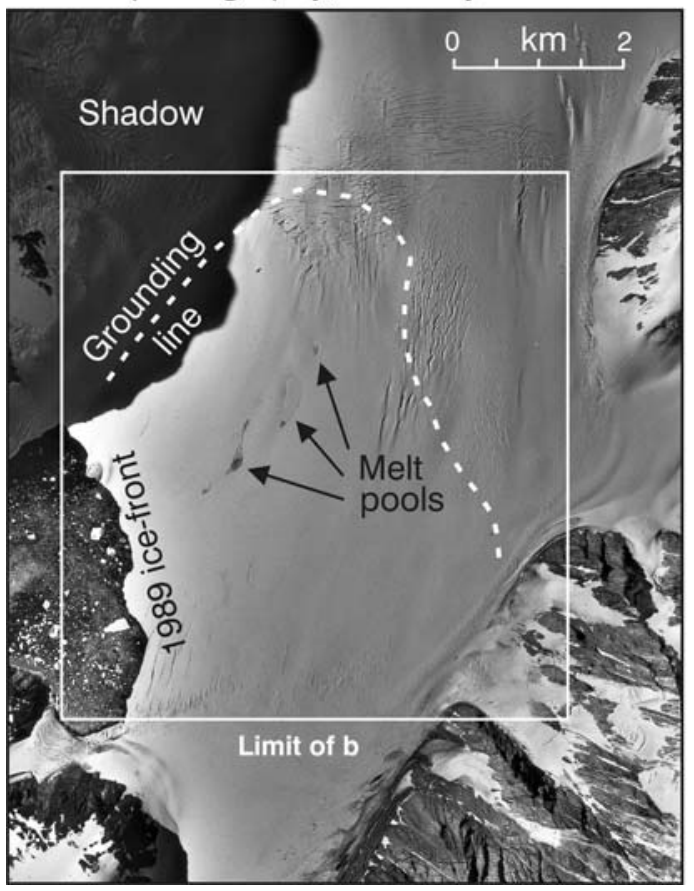

b BAS photography, January 2001

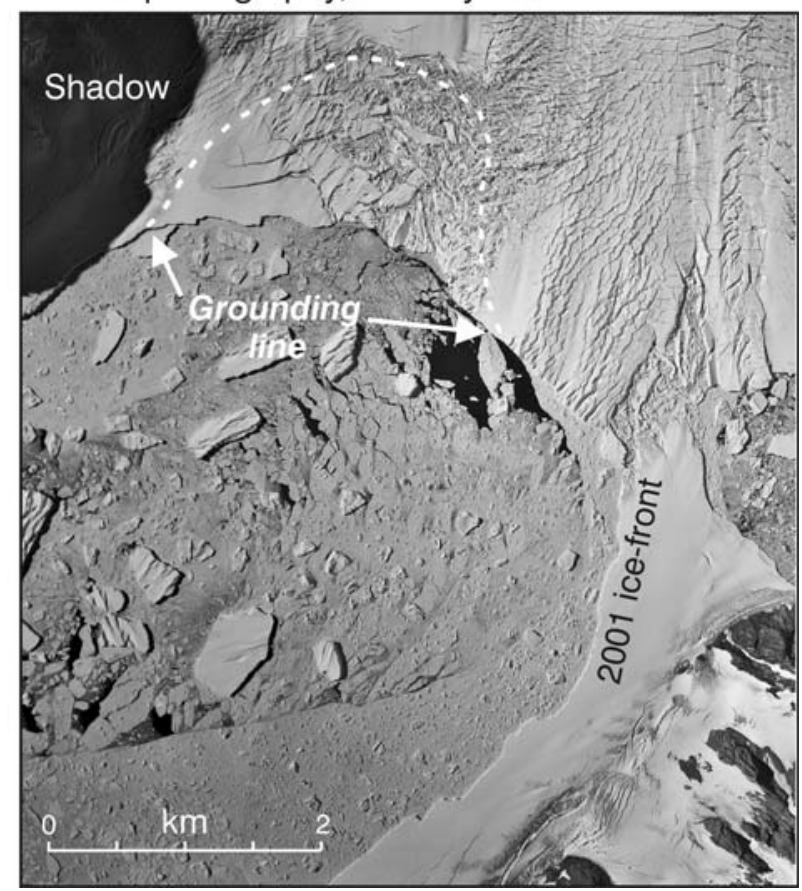

Fig. 5. Detail of Jones Ice Shelf in (a) 1989 and (b) 2001. The Jones Channel typically contains much remnant sea ice and floating ice.

shelf retreat, there are probably too few data to determine if it supports the other influential hypothesis concerning iceshelf retreat: that melt pools are both a precursor and a driver of rapid ice-shelf retreat (Scambos and others, 2000; Van den Broeke, 2005). Firstly, only a few melt pools (e.g. Fig. 5) have been identified on the surface of this ice shelf, even though all the imagery was acquired during the austral summer. However, it is possible that meltwater was present as a wider area of saturated firn rather than melt pools which still functioned as a water reservoir for fracturing of the shelf ice. Scambos and others (2000) described this effect for the Wilkins Ice Shelf. Secondly, there is no clear correlation between the number of positive degree-days, a good indicator for the volume of meltwater produced (Braithwaite and Zhang, 1999), and the rate of retreat, beyond a general observation that the retreat has occurred in a period of increasing positive degree-days. Figure $4 \mathrm{~b}$ shows positive degree-days for individual years for meteorological stations at Faraday/Vernadsky and Rothera (only $20 \mathrm{~km}$ from Jones Ice Shelf) alongside the progress of retreat. It is not possible to determine how well the episodes of retreat are correlated to years with high amounts of melt, and without more observations of ice-shelf extent, especially for the early period, such a comparison will not be possible in future.

Figure 5 shows that removal of the ice shelf has resulted in increased crevassing and could have coincided with an increase in ice velocity above the grounding line on Heim Glacier, although this has not been confirmed by direct observation; a similar effect was reported by Rott and others (2002) after the loss of Larsen A ice shelf.

\section{CONCLUSIONS}

Jones Ice Shelf has retreated in line with the other climatically driven ice-shelf retreats around the Antarctic Peninsula. After a period of relative stability between 1947 and 1968, retreat began and progressively accelerated without noticeable readvances. Thus the Jones Ice Shelf retreat further confirms the overall pattern that the limit of viability has migrated south with the recent rapid regional warming of the Antarctic Peninsula.

The western and eastern portions of Jones Ice Shelf lie in convergent and divergent embayments, respectively. Comparison of the retreat of the east and west portions supports modelling studies (Doake and others, 1998) which suggest that the geometry of the embayment modulates the pattern of retreat of an ice shelf and can sometimes produce a dramatic final-stage collapse.

Although surface melting has occurred on Jones Ice Shelf and may have been important to the overall progress of the retreat, there is insufficient evidence to determine whether melt-pooling caused specific retreat events, or that the size of a particular episode of retreat can be easily related to the degree of melting (cf. Scambos and others, 2000).

While the thickness of the ice shelf varies by a factor of three over the western part of the Jones Ice Shelf, it does not appear to be a controlling factor for the progress of retreat.

\section{ACKNOWLEDGEMENTS}

Constructive comments from T. Scambos and K. Cuffey significantly improved this paper.

\section{REFERENCES}

Braithwaite, R.J. and Y. Zhang. 1999. Relationships between interannual variability of glacier mass balance and climate. J. Glaciol., 45(151), 456-462.

Cook, A.J., A.J.Fox, D.G. Vaughan and J.G. Ferrigno. 2005. Retreating glacier fronts on the Antarctic Peninsula over the past half-century. Science, 308(5721), 541-544.

Doake, C.S.M. and D.G. Vaughan. 1991. Rapid disintegration of the Wordie Ice Shelf in response to atmospheric warming. Nature, 350(6316), 328-330. 
Doake, C.S.M., H.F.J. Corr, H. Rott, P. Skvarca and N.W. Young. 1998. Breakup and conditions for stability of the northern Larsen Ice Shelf, Antarctica. Nature, 391(6669), 778-780.

Hattersley-Smith, G. 1991. The history of place-names in the British Antarctic Territory. Br. Antarct. Surv. Sci. Rep., 113.

Lucchitta, B.K. and C.E. Rosanova. 1998. Retreat of northern margins of George VI and Wilkins Ice Shelves, Antarctic Peninsula. Ann. Glaciol., 27, 41-46.

MacAyeal, D.R., T.A. Scambos, C.L. Hulbe and M.A. Fahnestock. 2003. Catastrophic ice-shelf break-up by an ice-shelf-fragmentcapsize mechanism. J. Glaciol., 49(164), 22-36.

Mercer, J.H. 1978. West Antarctic ice sheet and $\mathrm{CO}_{2}$ greenhouse effect: a threat of disaster. Nature, 271(5643), 321-325.

Morris, E.M. and D.G. Vaughan. 2003. Spatial and temporal variation of surface temperature on the Antarctic peninsula and the limit of viability of ice shelves. In Domack, E.W., A. Burnett, A. Leventer, P. Conley, M. Kirby and R. Bindschadler, eds. Antarctic Peninsula climate variability: a historical and paleoenvironmental perspective. Washington, DC, American Geophysical Union, 61-68. (Antarctic Research Series, 79.)

Rott, H., W. Rack, P. Skvarca and H. De Angelis. 2002. Northern Larsen Ice Shelf, Antarctica: further retreat after collapse. Ann. Glaciol., 34, 277-282.
Scambos, T.A., C. Hulbe, M. Fahnestock and J. Bohlander. 2000. The link between climate warming and break-up of ice shelves in the Antarctic Peninsula. J. Glaciol., 46(154), 516-530.

Scambos, T., C. Hulbe and M. Fahnestock. 2003. Climate-induced ice shelf disintegration in the Antarctic Peninsula. In Domack, E.W., A. Burnett, A. Leventer, P. Conley, M. Kirby and R. Bindschadler, eds. Antarctic Peninsula climate variability: a historical and paleoenvironmental perspective. Washington, DC, American Geophysical Union, 79-92. (Antarctic Research Series, 79.)

Shepherd, A., D. Wingham, T. Payne and P. Skvarca. 2003. Larsen ice shelf has progressively thinned. Science, 302 (5646), 856-859.

Sievers, J., A. Grindel and W. Meier. 1989. Digital satellite image mapping of Antarctica. Polarforschung, 59(1-2), 25-33.

Van den Broeke, M. 2005. Strong surface melting preceded collapse of Antarctic Peninsula ice shelf. Geophys. Res. Lett., 32(12), L12815. (10.1029/2005GL023247.)

Vaughan, D.G. and C.S.M. Doake. 1996. Recent atmospheric warming and retreat of ice shelves on the Antarctic Peninsula. Nature, 379(6563), 328-331.

Vaughan, D.G., G.J. Marshall, W.M. Connolley, J.C. King and R. Mulvaney. 2001. Climate change: devil is in the detail. Science, 293(5536), 1777-1779.

Ward, C.G. 1995. Mapping ice front changes of Müller Ice Shelf, Antarctic Peninsula. Antarct. Sci., 7(2), 197-198.

MS received 14 May 2003 and accepted in revised form 19 October 2005 